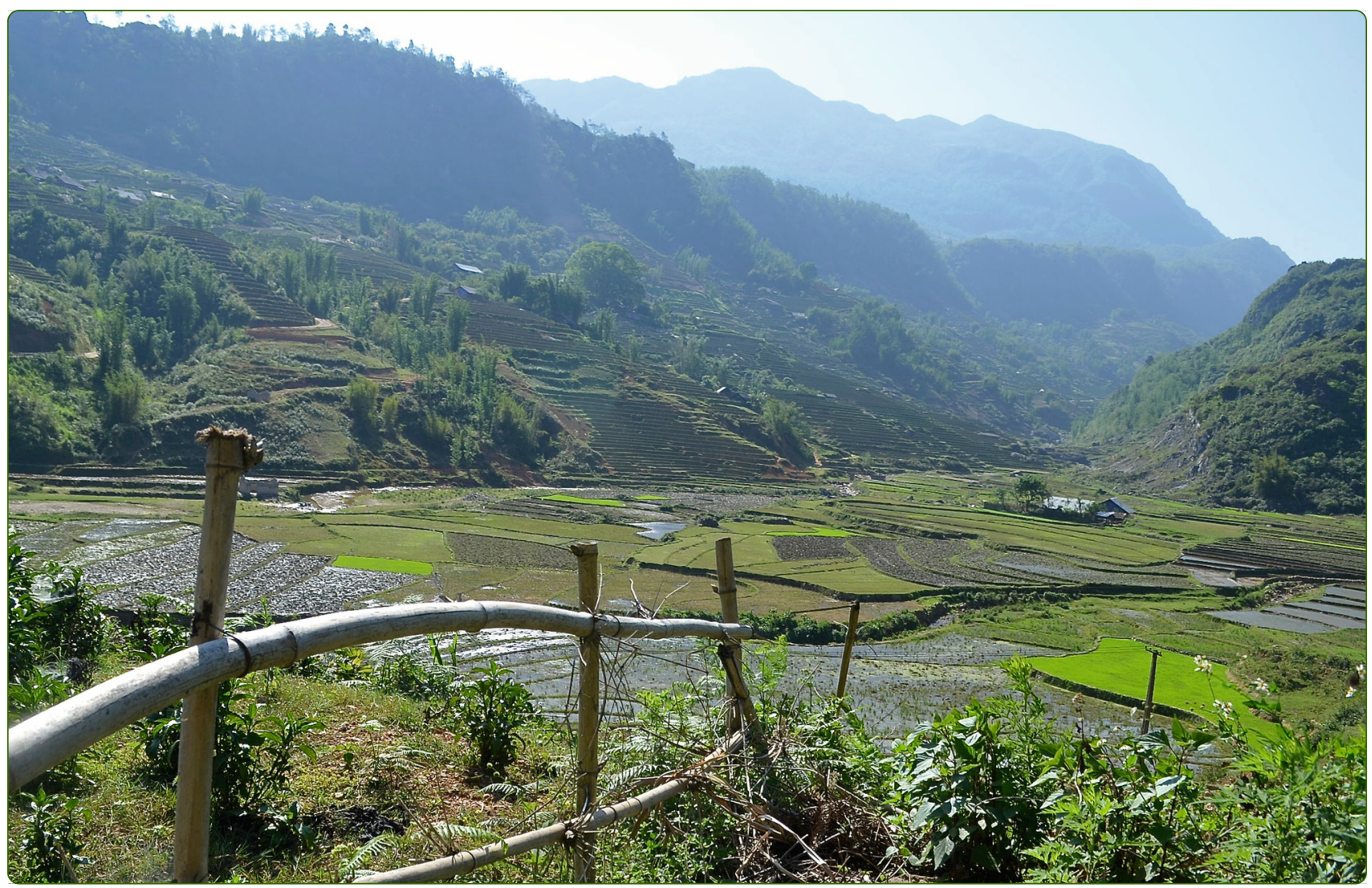

How effective are on-farm conservation land management strategies for preserving ecosystem services in developing countries? A systematic map protocol

Thorn et al.

C Biomed Central 


\title{
How effective are on-farm conservation land management strategies for preserving ecosystem services in developing countries? A systematic map protocol
}

Jessica Thorn ${ }^{1 *}$, Jake Snaddon², Anthony Waldron ${ }^{3}$, Kasper Kok ${ }^{4}$, Wen Zhou ${ }^{5}$, Shonil Bhagwat ${ }^{6}$, Kathy Willis ${ }^{1,7,8}$ and Gillian Petrokofsky ${ }^{1,5}$

\begin{abstract}
Background: An extensive body of literature in the field of agro-ecology claims to show the positive effects that maintenance of ecosystem services can have on sustainably meeting future food demand, by making farms more productive and resilient, and contributing to better nutrition and livelihoods of farmers. In Africa alone, some research has estimated a two-fold yield increase if food producers capitalize on new and existing knowledge from science and technology. Site-specific strategies adopted with the aim of improving ecosystem services may incorporate principles of multifunctional agriculture, sustainable intensification and conservation agriculture. However, a coherent synthesis and review of the evidence of these claims is largely absent, and the quality of much of this literature is questionable. Moreover, inconsistent effects have commonly been reported, while empirical evidence to support assumed improvements is largely lacking.

Objectives: This systematic map is stimulated by an interest to (1) collate evidence on the effectiveness of on-farm conservation land management for preserving and enhancing ecosystem services in agricultural landscapes, by drawing together the currently fragmented and multidisciplinary literature base, and (2) geographically map what indicators have been used to assess on-farm conservation land management. For both questions, we will focus on 74 low-income and developing countries, where much of the world's agricultural expansion is occurring, yet $80 \%$ of arable land is already used and croplands are yielding well below their potential.

Methods/Design: To this end, reviewers will systematically search bibliographic databases for peer-reviewed research from Web of Science, SCOPUS, AGRICOLA, AGRIS databases and CAB abstracts, and grey literature from Google Scholar, and 22 subject-specific or institutional websites. Boolean search operators will be used to create search strings where applicable. Ecosystem services included in the study are pollination services; pest-, carbon-, soil-, and water-regulation; nutrient cycling; medicinal and aromatic plants; fuel wood and cultural services. Outputs of the systematic map will include a database, technical report and an online interactive map, searchable by topic. The results of this map are expected to provide clarity about synergistic outcomes of conservation land management, which will help support local decision-making.
\end{abstract}

Keywords: Agro-ecology, Conservation agriculture, Sustainable intensification, Ecosystem services, In-field assessment, Site-specific management, Land sharing, Decision-making, Evidence-based environmental policy

\footnotetext{
* Correspondence: jessica.thorn@merton.ox.ac.uk

'Department of Zoology, Long-term Ecology and Resource Stewardship

Laboratory, Biodiversity Institute, University of Oxford, Oxford, UK

Full list of author information is available at the end of the article
} 


\section{Background}

Food production systems are threatened in the face of growing food demand, climate change and land cover changes [1]. Agriculture accounts for $70 \%$ of water withdrawals worldwide [2], one third of all available energy [3], 75\% of all deforestation [4], 19-29\% of global GHG emissions, and is the largest contributor of non-CO2 GHG emissions [5]. Declines in ecosystem health have consequences for agricultural production, such as soil salinization from over-irrigation and eutrophication of watercourses from fertilizer application. Forty percent of arable land worldwide is already degraded [6]. Moreover, these trends are increasing as agriculture intensifies and expands. For example, between 1961-2005 agricultural production doubled in Sub-Saharan Africa [7], and globally, was one of the main drivers of degradation of $65 \%$ of natural ecosystems [8]. In the last century, forest cover decreased from 170-100 million ha and every year, palm oil cultivation is responsible for c. 300000 ha of forest cover loss [9]. In the next 25 years, food production and availability must increase by $50-70 \%$ to keep pace with the demands of a global population expected to reach 8-10 billion, income growth, and changing consumer preferences $[6,10]$. To address these challenges, recent international meetings have been convened, such as the UN Summit of 2014, where leaders from 20 governments and 30 organizations pledged their commitment to addressing food security through the formation of the Global Alliance for Climate-Smart Agriculture. Balancing the need to provide enough food for a growing population while maintaining healthy ecosystems and habitats is thus arguably one of the most pressing issues of the $21^{\text {st }}$ century $[1,6]$.

\section{Ecosystem services as incentives for conservation agricultural land management}

An emerging strategy being championed for conservation is the ecosystem service framework, which proponents consider more likely to be relevant to agricultural landscapes and their associated people than traditional biodiversity conservation $[11,12]$. The ecosystem services framework can be used to capture how human action both impacts and is affected by ecosystem responses to land use and land use changes [13].

Although various comprehensive frameworks and classifications refined and omitted categories [14,15], the framework for ecosystem services referred to is based on the Millennium Ecosystem Assessment (MA) [8], as this was the first large-scale ecosystem service assessment and categories are widely recognized [16]. This includes supporting services (e.g. carbon regulation, pest regulation, nutrient cycling), regulating services (e.g. water/soil regulation and supply, pollination services), provisioning services (e.g. fuel wood, medicinal and aromatic plants) and cultural services (e.g. education, recreational, spiritual, tourism, bequest or aesthetic value). Ecosystem goods and services are stocks or flows of materials that deliver welfare gains or losses that are material (e.g. fuel wood), as well as non-material (e.g. recreational services) [17]. Ecosystem elements are both biotic and abiotic and are generally described in terms of amounts (e.g. taxonomic, functional, chemical or physical units) [18-20]. Ecosystem processes, often used interchangeably with ecosystem functions, are the complex interactions (e.g. events, reactions or operations) among elements of ecosystems (e.g. events, reactions or operations), and are generally described in terms of rates [21].

Since the publication of the MA in 2005, the ecosystem services framework has gained traction - in terms of research, a spectrum of tools, and funding mechanisms $[22,23]$. Dedicated journals have been launched (e.g. International Journal of Biodiversity Science in 2005, Ecosystem Services and Management in 2005, Ecosystem Services in 2012), alongside graduate programs (e.g. MSc in Ecosystem Services, University of Edinburgh). Funding bodies are also prioritizing research into more comprehensive quantification of values of ecosystem services and the link with human health and wellbeing, such as the $\$ 65 \mathrm{~m} 7$ year programme on Ecosystem Services and Poverty Alleviation (ESPA) and the $\$ 11 \mathrm{~m}+6$ year Valuing Nature programme led by the National Environment Research Council [24]. Moreover, ecosystem services projects attract on average more than four times as much funding as traditional biodiversity conservation projects, through greater corporate sponsorship and a wider variety of finance tools [11]. Supported by this research, there is a growing spectrum of ecosystem assessment tools, including computer-based platforms using national data (e.g. Integrated Valuation of Ecosystem Services and Trade-offs (InVEST), modelling and scenario driven tools (e.g. MIMES, ARIES), as well as efforts to integrate these frameworks (e.g. the Common International Classification on Ecosystem Services (CICES)). The ecosystem services framework has been used for international negotiation and collaboration in platforms, such as the Ecosystem Services Partnership in 2008, the International Panel on Biodiversity and Ecosystem Services in 2012, and the EU 2020 Biodiversity Strategy (e.g. Target 2) [1]. National governments have also incorporated ecosystem services frameworks to inform budget assignment and thematic planning prioritization, such as the UK's National Ecosystem Service Assessment [17] and Foresight Report [1], that relates ecosystem services to agriculture and food security. The approach has further gained traction in the private sector, and has been used to conduct economic valuations in carbon (e.g. Voluntary Carbon Standard in South Africa), timber (e.g. Reduced Emissions from Deforestation and Degradation (REDD+) in Nigeria) and 
watersheds (e.g. Payments for Ecosystem Services in Costa Rica) [25].

\section{The role of conservation land management in} maintaining ecosystem services

Given the importance of ecosystem services to the sustainability and security of agricultural systems, as well as the current rate at which those services are being degraded by agricultural systems, a key need has arisen to implement ecosystem service conservation strategies on farms. A variety of alternative practices to conventional or intensive agriculture have been proposed, which we group under the term "conservation land management" for the purposes of this study. Conservation land management strategies preserve or enhance ecosystem services without compromising farm production and may be adopted before, during or after cultivation [26]. Strategies may be active, such as surface crop residue management, or passive, such as the existence of native vegetative patches in fields. Practices may incorporate principles, amongst others, of multifunctional agriculture (producing food and non-food commodities, maintaining wild crop varieties, traditional landraces and local culture [27]), sustainable intensification (relieving pressure on land expansion and limiting forest encroachment [7]), and conservation agriculture (practices of no-tillage, permanent soil cover using crop residues or cover crops, and crop rotation [28]). Such practices often require minimal inputs with opportunities for enhancing small-holder production [26].

Specific examples of conservation land management strategies include growing leguminous cover crops to fix nitrogen, retain moisture, stimulate root-growth and encourage below-ground microbial activity [29]; no till or minimum till systems and crop rotation, to influence soil organic carbon sequestration [26,30] and yield [26]; mosaic or matrix management of natural vegetation within or adjacent to farmland (e.g. set aside areas, buffer strips, hedgerows or field margins), to encourage the presence of beneficial wild pollinator populations [31]; fallowing to suppress leaching and erosion of organic matter and nutrients, and increase soil cation exchange [32]; intercropping and the use of push-pull systems to regulate detrimental pest populations and enhance natural enemy populations [33]; water conservation techniques, such as drip irrigation, alternative wet and dry irrigation, raised beds, tied ridges and ditches, and growing grass filter strips, to influence water regulation and supply and control erosion [34,35]; and the intercropping of timber trees with shade tolerant crops, or multi-story cropping, to reduce the presence of weeds and promote nutrient cycling [27]. To conceptualize a theory of change, Figure 1 shows examples of conservation land management strategies (single programs or comprehensive community initiatives)

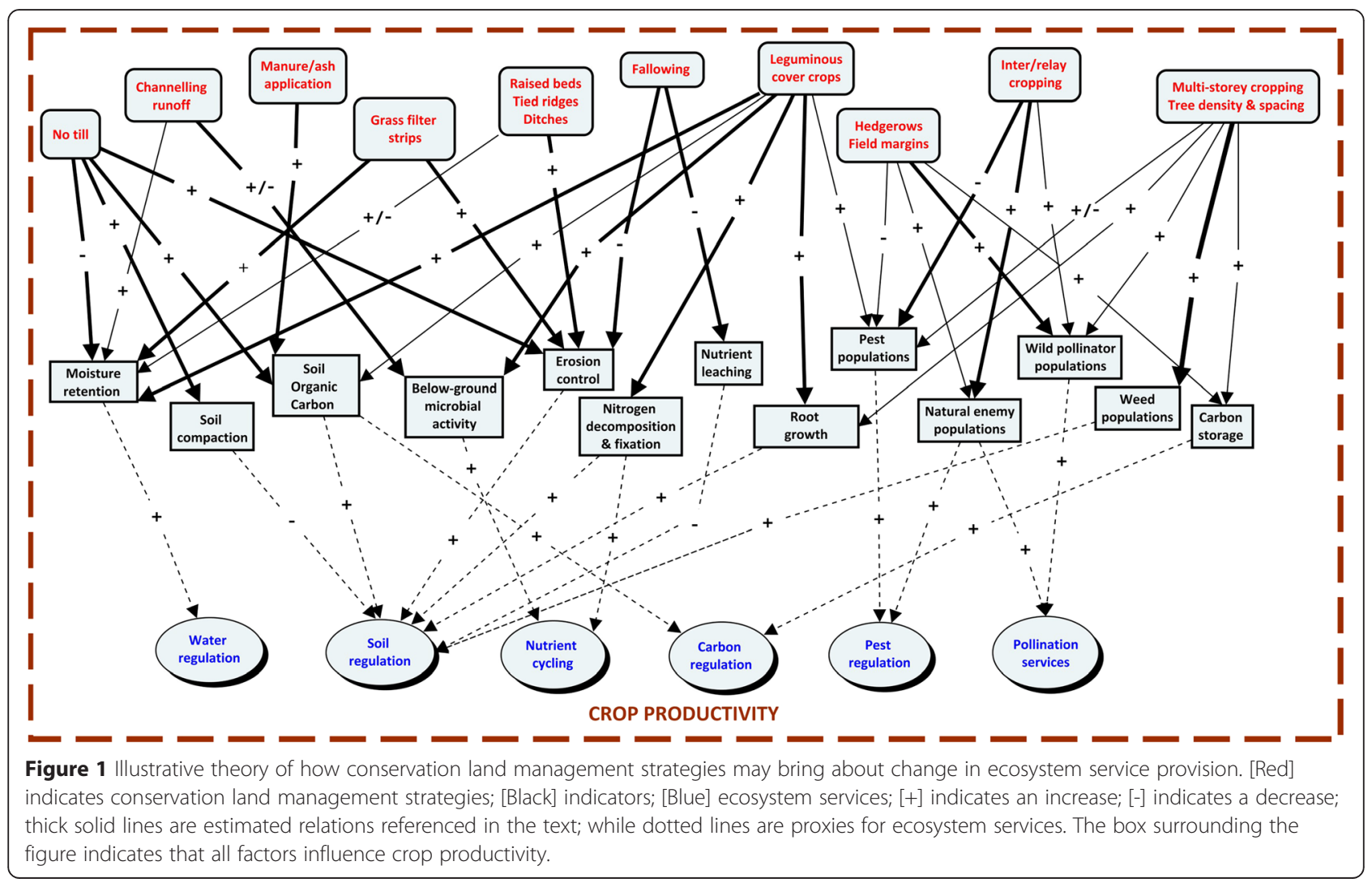


(red) that may bring about outcomes on supporting or provisioning ecosystem services (blue), through key measurable indicators or proxies (black).

The figure illustrates the complex web of activity that is required to bring about change, while assumptions indicated in the flow arrows are not exclusive or exhaustive, and require varying degrees of research verification. We still lack a coherent evidence base showing how effectively these management strategies preserve or enhance ecosystem services overall.

Synthesizing evidence is complex for three main reasons. Firstly, change in conservation land management may affect various ecosystem services differently. For example, some studies report that long-term no-till can improve soil fertility, recovery and decrease erosion, but no-till can also lead to soil compaction, limit water infiltration and can hinder seed germination [36,37]. Other studies have reported that managing runoff can increase and stabilize crop production and deposit plant nutrients in soil, but runoff can adversely affect nutrient cycling [38]. The management of ecosystem services therefore requires making judgements about trade-offs, not least, the trade-off between agricultural production and environmental protection [23]. Secondly, impacts of land management on ecosystem services are often quantified by indicators or proxies of ecosystem processes, thought to subsequently impact ecosystem services. However, evidence for the adequacy of these proxies is often incomplete or inconsistently reported. For example, many studies suggest higher biodiversity allows for higher levels of ecosystem service provision [39], while others argue there is little hard evidence to show the necessity of a diversity of natural enemies in regulating pests on farms [40]. Thirdly, much of the evidence is spread across different disciplinary "silos", with very limited synthesis. Some studies also overstate the benefits of land management strategies [37].

Land managers, and other parties interested in ecosystem services, would benefit from much greater clarity and information on the effectiveness of conservation land management strategies, in order to decide which management strategies to implement at the farm level. When evidence is so extensive and disparate, a rapid first step in such an informational synthesis is a systematic map, a rigorous methodological tool of data extraction of peer-reviewed and grey literature [41]. Systematic maps have the same precision as a review, while no evidence synthesis is attempted and a critical appraisal of the quality of evidence is limited in depth $[42,43]$. Previous attempts to synthesize this body of research have focused on particular regions, such as Africa $[44,45]$, a limited set of practices [28], or have evaluated management outcomes purely in terms of crop responses [45]. Our systematic map will build on this research, both geographically, and in terms of the management strategies and ecosystem services studied.

Against this background, the aim of this systematic map is to review the state of evidence that reports on the effectiveness of on-farm conservation land management for protecting or enhancing ecosystem services. First, we aim to provide a better summary of different strategies proposed and tested, in which crops, habitats and regions, and over what timeframes. Secondly, we will identify the pathways by which practices are assumed to influence ecosystem service provision by reporting on measurable indicators assessed in studies. We will differentiate between methodologies that are experimental, quasi-experimental and non-experimental and indicators that are physical, chemical, biological, social and/or economic. The spatial scale of the study is at the field level, as this is the scale at which most decisions for land management are made and need to be informed [46]. Our geographical coverage will be developing regions, as this is where much of agricultural expansion is occurring [1], yet $80 \%$ of arable land is already used [47] and croplands are yielding well below their potential [4]. In some cases, developing regions may also depend on ecosystem services rather than technological inputs to support agriculture, due to lower financial, technical and credit-borrowing capacity.

\section{Objectives of the systematic map}

1. Collate studies providing evidence on the effectiveness of on-farm conservation land management practices on ecosystem service provision in agricultural landscapes in low-income and developing countries.

2. Geographically map which indicators have been used for on-farm assessments of conservation land management in low-income and developing countries.

3. Produce an online interactive map, searchable by topic.

\section{Elements of the systematic map question}

Population: Farms in low/middle income and developing countries.

Intervention: Conservation land management strategies adopted to support productive agriculture, while simultaneously preserving or enhancing ecosystem services.

Comparators: Farms without conservation land management strategies, conventional/intensive agriculture or natural sites.

Outcomes: Measured changes in ecosystem services, including supporting services (e.g. carbon regulation, pest regulation, nutrient cycling), regulating services (e.g. water/soil regulation and supply, pollination services), provisioning services (e.g. fuel wood, medicinal and 
aromatic plants) and cultural services (e.g. education, recreational, spiritual, tourism, bequest or aesthetic value).

\section{Method}

\section{Search strategy}

The following search strategy and research question have been developed with stakeholders in two meetings in South Africa (February 2014) and UK (June 2014). Expertise of stakeholders span the fields of environment, conservation, biodiversity, development, agriculture, entomology, soil science, pollination, anthropology and ecology. Further comments on earlier drafts of this protocol were provided after the workshops and over email with other contributors (Additional file 1).

\section{Language}

The systematic map will be limited to studies published in English. This decision was made as the larger body of literature is in English, as well as this being the linguistic competency of the review team and also provides a mechanism for restricting the scale of the study $[41,48]$. Should a full systematic review be conducted arising from the map, French, Spanish or Portuguese would be considered to cover literature from regions in Africa, South East Asia and Latin America. Future assessments will create language-specific search strings associated with the research question.

\section{Key search terms}

A list of key terms, searched at levels of title, and abstract level is listed in Additional file 2. Each of the terms relate to the components of the research question and PICO (Population Intervention Comparator Outcome). The list was compiled by experts from invited institutes and universities, who met at the two stakeholder workshops. Terms were built into strings, used in preliminary scoping searches conducted in the Web of Science (WOS) CAB Abstracts, and Google Scholar. In WOS 27 search strings were tested, with the final string resulting in 7558 hits. The search strategy contains synonyms and near-synonyms, and does not make a distinction between definitions used in the primary literature. We will use these strings as the basis of the search, however an iterative approach to identifying search terms will be adopted to improve the strategy and help minimize bias. Details of the search logic and the development of the final strings are found in Additional file 3. Boolean search operators will be used to connect search terms in the usual way and subject to the specific rules of individual databases. In the search wildcards will be used with care and will vary slightly from database to database. Such variations between search strategies in each database and source will be documented and reported in the final map. The date of the search will be documented, allowing for updating of future mapping.

\section{Sources of publications Bibliographic databases}

The following bibliographic databases will be considered, covering material from the natural and social sciences, from both peer-reviewed and grey literature:

1. Thomson Reuter's (formally ISI) Web of Science, New York, USA http://apps.webofknowledge.com/

2. Elseviers' SCOPUS http://www.elsevier.com/ online-tools/scopus

3. $\mathrm{CAB}$ Abstracts published by $\mathrm{CAB}$ International, Wallingford, UK http://www.cabdirect.org/

4. AGRICOLA Agricultural Research Database http:// www.ebscohost.com/academic/agricola

5. AGRIS Agricultural Science and Technology Information Systems http://agris.fao.org/agris-search/ index.do

\section{Search engine searching}

In addition to the results from the above-mentioned agricultural and forestry databases, the meta-search engine platform Google Scholar (http://scholar.google.com) will be searched to access studies not captured in the above databases. The first 200 search results will be assessed at the level of title and abstract. Results, organized by relevance, will be compared to results of existing searches in bibliographic databases, and added to the reference list.

\section{Targeted searches}

Targeted searches will be conducted to source peerreviewed and grey literature, including searching particular journals, specialist organizations, online databases and individual research papers. This will be restricted to .pdf or word documents available online. Results will be compared to searches from bibliographic databases and omitted papers included in the reference file.

\section{Individual journals}

First, we will hand search individual e-journals whose topic areas are closely aligned with our research question, based on the outcomes of searches using bibliographic databases. Journals include Ecological Indicators, Ecosystem Services, Integrated Environmental Assessment and Management and Agriculture, Ecosystems and Environment and Field Crop Research.

\section{Key research papers and case studies through stakeholder engagement}

Second, key research papers, reports and case studies relevant to the research question will further be identified by 
(a) two stakeholder workshops with experts in key thematic areas, in Cape Town, South Africa and Oxford, UK; (b) online calls on the Oxford Long-Term Ecology Lab and CIFOR websites and (c) consultations with an advisory board of experts throughout 2014/5. We will rely on the advisory panel to recommend relevant dissertations, where the rich data has not been published in academic journal. Snowball sampling techniques will be used to identify further literature and will help minimize selection bias.

\section{Grey literature for specialist searching}

Third, a grey literature search will include organizational reports, conference papers or proceedings and policy briefs, station and annual reports, found on searches of subject-specific websites and institutional websites (Table 1). Specialist organizations listed include research organizations, national/bi-multi-lateral organizations, donors, and private industry that work the sector in agricultural land management and conservation. Key terms used to search grey literature will be amended as compared to strings used for peer-reviewed bibliographic databases. Literature will be searched through thematic (e.g. agricultural biodiversity) and geographic areas (e.g. Africa, Asia) and simple key terms based on a subset of search terms (e.g. (ecosystem OR ecological OR environmental) AND (function OR service OR good OR process)

Table 1 Websites of specialist organizations and online databases

\begin{tabular}{|c|c|}
\hline Organization & Website \\
\hline Centre for International Forestry (CIFOR) & http://www.cifor.org/library/ \\
\hline Consultative Group for International Agricultural Research (CGIAR) & www.cgiar.org/resources/cgiar-library \\
\hline Alliance for a Green Revolution in Africa (AGRA) & http://agra-alliance.org \\
\hline International Rice Research Institute (IRRI) & http://irri.org \\
\hline International Centre for Tropical Agriculture (CIAT) & http://ciat-library.ciat.cgiar.org \\
\hline Integrated Water Management Institute (IWMI) & www.iwmi.cgiar.org \\
\hline International Institute of Tropical Agriculture (IITA) & www.iita.org/ \\
\hline International Potato Centre (CIP) & http://cipotato.org \\
\hline Africa Rice Centre (AfricaRice) & www.africarice.org \\
\hline World Resources Institute (WRI) & www.wri.org/ \\
\hline $\begin{array}{l}\text { International Crops Research Institute for the Semi-Arid } \\
\text { Tropics (ICRISAT) }\end{array}$ & http://oar.icrisat.org/cgi/search/advanced \\
\hline Climate Change Agriculture and Food Security (CCAFS) & http://ccafs.cgiar.org/publications \\
\hline World Agroforestry Centre (ICRAF) & http://outputs.worldagroforestry.org \\
\hline $\begin{array}{l}\text { International Center for Agricultural Research in the Dry } \\
\text { Areas (ICARDA) }\end{array}$ & http://www.icarda.org/ \\
\hline $\begin{array}{l}\text { Comprehensive Africa Agriculture Development } \\
\text { Programme (CAADP) }\end{array}$ & http://www.caadp.net/ \\
\hline Institute of Environment and Agricultural Research (INRA) & www.inra.fr/en/liste/dossiers/76 \\
\hline Monsanto Agricultural & www.monsanto.com/products/pages/biotech-technical-publications.aspx \\
\hline Syngenta Foundation & http://www.syngentafoundation.org/index.cfm \\
\hline Department for International Development (DFID) & http://r4d.dfid.gov.uk/ \\
\hline Ecosystem Services Partnership (ESP) & www.es-partnership.org \\
\hline Ecoagriculture Partners & www.ecoagriculture.org/publications.php \\
\hline International Union for the Conservation of Nature (IUCN) & www.iucn.org/knowledge/publications_doc/publications/ \\
\hline United Nations Development Programme (UNDP) & www.undp.org/content/undp/en/home/librarypage.html \\
\hline Overseas Development Institute (ODI) & www.odi.org/publications \\
\hline International Maize and Wheat improvement (CIMMYT) & http://repository.cimmyt.org/xmlui/discover \\
\hline The Economics of Ecosystems and Biodiversity (TEEB) & www.teebweb.org \\
\hline Convention of Biological Diversity (CBD) & www.cbd.int \\
\hline Bioversity International & www.bioversityinternational.org/e-library/publications/ \\
\hline Practical Action & http://practicalaction.org/publishing \\
\hline International Institute on Environment and Development (IIED) & http://pubs.iied.org \\
\hline
\end{tabular}


AND (farm OR agriculture OR agro-ecosystems OR agroecology OR cultivation OR crops OR conservation agriculture) AND (impact OR assess OR method OR protocol)). To assist in the screening in the grey literature, text extraction software will be used to identify relevant key words and strings related to the research questions.

\section{Comprehensiveness of search}

Alternative terms for the search have been tested using a test library (Additional file 4), and disaggregated using wildcard and other variations of similar words to ensure key literature relevant to the research question is picked up in the search, as well as to ensure specificity.

Searches using strings in the test library adequately picked up studies assessing the effects of conservation land management on ecosystem processes, as well as ecosystem service impacts on agricultural production (e.g. pollination). Results identified studies that quantify specific ecosystem services or disservices, or assess how conservation agricultural land management strategies benefit or degrade ecosystem services.

Site-specific land management strategies included, amongst others, organic (e.g. ash, biochar, straw, urea, farmyard manure) and inorganic fertilizer application (NPK), mulching or surface crop residue retention, crop rotation, inter-/relay- cropping, tied/raised ridges and ditches, hedgerows, field margins, grass filter strips, integrated pest and weed management, terracing, hand pollination, cover cropping, mosaic/matrix management, fallowing, reforestation, multipurpose agroforestry crops, and various tillage regimes.

Studies employed methodologies from the social, economic and natural sciences. Amongst others, various studies assessing soil measured soil organic material, and chemical properties of $\mathrm{pH}$, macronutrients and heavy metals, and physical properties such as soil bulk density and texture. Nutrient cycling was measured through proxies of microbial activity and biomass, while various studies measured biodiversity metrics looking at community composition of key taxonomic indicators. Assessments of carbon services assess above/below-ground biomass, growth and survival rate of trees, stem diameter at breast height and density. Pollination service assessments measured visitation rates, flower pulp analysis, fruit set, and arthropod diversity and abundance. Social indicators included yield, income, farm size, and amounts harvested. Table 2 presents some of the coding variables to be used in the systematic map, with results extracted from studies in the test library.

\section{Study screening, inclusion and exclusion criteria}

Search results from all databases will be exported into library folders in EndNote reference manager, and duplicates removed in a common folder. The final set of citations will be screened against the following eligibility criteria by five reviewers. Each study will be assessed for inclusion sequentially at title, abstract stages, and full text. At the beginning of each stage of screening, Kappa analysis will be performed by the four reviewers to confirm agreement between them on a random subset of 100 studies. An online calculator for free-marginal kappa will be used, available at http://justusrandolph.net/ kappa/ [49]. If the kappa coefficient is below 0.6, then the kappa analysis will be repeated on additional sets of randomly selected studies until agreement reaches at least 0.6. The reviewers will use DateX systematic review evaluation software [50] to document their decisions. Exclusion of studies will be conservative, and to supplement the kappa analysis of agreement, random samples of rejected studies will be examined and any disagreements between the reviewers discussed and resolved through regular meetings.

\section{Relevant population}

- Relevant farming systems will include terrestrial food and cash crops, including cereals, grains, roots and tubers, pulses, vegetables oilseeds and tree oils and agroforestry crops that are multipurpose trees for food, fodder, fuel, medicine and shade. Crops are categorized according to the FAO 2012/13 major commodities list [51]. Mixed and mono-cropping systems will be included, as will organic, conventional, hybrid and genetically-modified crops. Marine biomes or mangroves with maricultural or aquacultural activities will be excluded (see Liquete et al [52] for a review on marine ecosystem services), as will livestock farming and pastures (land covered with grass or other plants suitable for grazing).

- Countries to be included in the study have been selected from three databases of globally-recognized organizations working to improve ecosystem services, reduce food insecurity and support economic development (based on FAO 2013, WB 2014, ESPA 2014 [53-55]). The list of 74 countries, details of the motivation of this classification, together with a description of calculations, is found in Additional file 5 .

\section{Relevant intervention}

- Studies assessing a conservation land management strategy with the aim to improve ecosystem services will be included. Studies describing general biology, foraging/behavioural/spatial ecology, growth behaviour of crops, DNA markers that reveal genetic phylogeny or reporting plant-breeding 
Table 2 Examples from the test library summarizing conservation land management strategies assessed, ecosystem services measured, indicators (non-exclusive), crops and country of assessment

\begin{tabular}{|c|c|c|c|c|c|c|c|c|}
\hline $\begin{array}{l}\text { Conservation land } \\
\text { management }\end{array}$ & $\begin{array}{l}\text { Ecosystem } \\
\text { service }\end{array}$ & $\begin{array}{l}\text { Properties } \\
\text { studied }\end{array}$ & Indicators & Crop & Country & Publication & Year & Authors \\
\hline $\begin{array}{l}\text { Native vegetative } \\
\text { patches in farmland }\end{array}$ & Pollination & Biological & $\begin{array}{l}\text { Flower visitation } \\
\text { networks, seed mass, } \\
\text { honeybee and visitor } \\
\text { abundance }\end{array}$ & Sunflower & $\begin{array}{l}\text { South } \\
\text { Africa }\end{array}$ & $\begin{array}{l}\text { Ecology } \\
\text { Letters }\end{array}$ & 2011 & $\begin{array}{l}\text { Carvalheiro, L. G., } \\
\text { Veldtman, R., Shenkute, } \\
\text { A. G., Tesfay, } \\
\text { G. B., Pirk, C. W. W., } \\
\text { Donaldson, J. S., and } \\
\text { Nicolson, S. W. }\end{array}$ \\
\hline $\begin{array}{l}\text { Reforestation, crop } \\
\text { rotation }\end{array}$ & $\begin{array}{l}\text { Soil, } \\
\text { carbon }\end{array}$ & $\begin{array}{l}\text { Chemical } \\
\text { and biological }\end{array}$ & $\begin{array}{l}\text { Soil organic carbon, } \\
\text { microbial biomass, } \\
\text { dissolved organic } \\
\text { carbon }\end{array}$ & Rice & China & $\begin{array}{l}\text { Journal } \\
\text { of Plant } \\
\text { Ecology }\end{array}$ & 2013 & $\begin{array}{l}\text { Cui, J., Zhang, R., Bu, } \\
\text { N., Zhang, H., Tang, B., } \\
\text { Li, Z., Jiang, L., Chen, J. } \\
\text { and Fang, C. }\end{array}$ \\
\hline $\begin{array}{l}\text { Surface crop residue } \\
\text { retention, crop } \\
\text { rotation, ridge and } \\
\text { furrow systems, } \\
\text { legume intercrop }\end{array}$ & $\begin{array}{l}\text { Water, soil, } \\
\text { carbon }\end{array}$ & $\begin{array}{l}\text { Chemical } \\
\text { and physical }\end{array}$ & $\begin{array}{l}\text { Water infiltration rates, } \\
\text { soil moisture, soil organic } \\
\text { carbon, texture, NPK, } \\
\text { heavy metals }\end{array}$ & Maize & Malawi & $\begin{array}{l}\text { Field Crops } \\
\text { Research }\end{array}$ & 2013 & $\begin{array}{l}\text { Thierfelder, C., Chisui, } \\
\text { J. L., Gama, M., } \\
\text { Cheesman, S., Jere, F. } \\
\text { D., Bunderson, W. T., } \\
\text { Eash, N. S. and } \\
\text { Rusinamhodzi, L. }\end{array}$ \\
\hline $\begin{array}{l}\text { Fallowing with } \\
\text { pigeon pea and } \\
\text { elephant grass }\end{array}$ & $\begin{array}{l}\text { Soil, } \\
\text { carbon, } \\
\text { biodiversity }\end{array}$ & $\begin{array}{l}\text { Chemical } \\
\text { and biological }\end{array}$ & $\begin{array}{l}\text { Soil organic carbon, pH, } \\
\text { enzyme activity, } \\
\text { microbial biomass }\end{array}$ & Maize & Ghana & $\begin{array}{l}\text { Soil Biology } \\
\text { and Biochemistry }\end{array}$ & 2008 & $\begin{array}{l}\text { Asuming-Brempong, S. } \\
\text { Gantner, S., Adiku, } \\
\text { S.G.K., Archer, G., } \\
\text { Edusei, V. and } \\
\text { Tiedje, J. M. }\end{array}$ \\
\hline $\begin{array}{l}\text { Agroforestry with } \\
\text { herbaceous, shrub } \\
\text { and tree species } \\
\text { strips }\end{array}$ & $\begin{array}{l}\text { Carbon, } \\
\text { Soil }\end{array}$ & $\begin{array}{l}\text { Chemical } \\
\text { and biological }\end{array}$ & $\begin{array}{l}\text { Soil organic carbon, } \\
\text { species diversity and } \\
\text { composition, pH, soil } \\
\text { exchangeable cations, } \\
\text { NPK }\end{array}$ & Oil palm & Brazil & $\begin{array}{l}\text { Agroforestry } \\
\text { Systems }\end{array}$ & 2014 & $\begin{array}{l}\text { de Carvalho, W. R., } \\
\text { Vasconcelos, S. S., Kato, } \\
\text { O. R., Capela, C. J., B., } \\
\text { and Castellani, D. C. }\end{array}$ \\
\hline $\begin{array}{l}\text { No-till, fallowing, } \\
\text { farmyard manure } \\
\text { and crop residue } \\
\text { mulching }\end{array}$ & $\begin{array}{l}\text { Carbon, } \\
\text { soil, water }\end{array}$ & $\begin{array}{l}\text { Chemical } \\
\text { and physical }\end{array}$ & $\begin{array}{l}\text { Soil organic carbon, soil } \\
\text { texture, water } \mathrm{pH} \text {, total } \\
\text { base cations, bulk } \\
\text { density, nitrogen }\end{array}$ & Cotton & $\begin{array}{l}\text { Burkina } \\
\text { Faso }\end{array}$ & $\begin{array}{l}\text { Nutrient } \\
\text { Cycling in } \\
\text { Agro-ecosystems }\end{array}$ & 2006 & $\begin{array}{l}\text { Ouattara, B., Ouattara, } \\
\text { K., Serpantié, G., } \\
\text { Mando, A., } \\
\text { Sédogo, M., } \\
\text { and Bationo, A. }\end{array}$ \\
\hline $\begin{array}{l}\text { Fallowing over } \\
\text { various time periods }\end{array}$ & $\begin{array}{l}\text { Carbon, } \\
\text { biodiversity }\end{array}$ & Biological & $\begin{array}{l}\text { Tree and shrub structure, } \\
\text { floristic species richness, } \\
\text { diversity, stem density, } \\
\text { biomass }\end{array}$ & Tobacco & Tanzania & $\begin{array}{l}\text { African } \\
\text { Journal of } \\
\text { Ecology }\end{array}$ & 2005 & Mangora, M. M. \\
\hline
\end{tabular}

methods, the development of improved cultivars or the selection of genotypic traits in plants will be excluded. Studies assessing only land uses differentiated by crop type will be excluded.

\section{Relevant outcomes}

- Changes in ecosystem services measurable at the field level will be included, though some processes will also influence the state of the ecosystem service at broader spatial scales (e.g. carbon sequestration influenced by global processes, or water regulation and supply influenced by catchment level processes). Services may be referred to specifically (e.g. soil organic content in the rhizosphere under alternate tillage regimes [56]), or more broadly (e.g. cultural services of Bedouin in Jordan [57]). However, studies on disease or nutrition outcomes will be excluded, including vector-borne diseases (e.g. malaria or typhoid management in irrigated systems) or fungal pathogens, as well as studies measuring off-farm non-timber forest products. Studies assessing only outcomes on yield or income will be excluded.

\section{Relevant types of study design}

- The spatial scale of the study is at the field level. Studies to be included are grounded, empirical assessments, field-based, or correlative experiments in natural environments. Studies assessing the impacts of land uses off the farm will be excluded (e.g. acid mine drainage influencing yield) or climatic influences (e.g. temperature or rainfall changes influencing crop phenology). Purely lab-based manipulative experiments including microscopy, infrared reflectance spectroscopy, chromatography, pot-based/green-house experiments will be excluded. Ex-situ methods of assessing services using remote sensing or modelling (e.g. crop simulation modelling) will be excluded. We will not adopt a strict definition 
of 'farm' and include studies in agricultural mosaics. This is because service provision in farmland boundaries (e.g. pollination by arthropods) may be affected by adjacent protected areas, riparian strips, buffer zones and the wider farming community.

- Single year and chronosequences assessing inter-annual variation, seasonal changes or interdecadal studies will be included. Long-term paleoecology studies will be excluded. Studies assessing the impact of land management during or after cultivation are included.

- Studies on ecosystem services that provide conceptual frameworks, assess regulatory/legislative frameworks, market access or information for farmers, as well as scientific reviews, meta-analyses, literature reviews, studies validating earlier estimates, clinical trials, patents or datasets will be excluded. Records of local ecological knowledge for assessing ecosystem services, beyond that which is captured in the literature search (e.g. unpublished interview transcripts, video interviews) will be excluded.

- Studies using social and ecological data will be included, while studies that look at economic valuation only (e.g. stated preferences or willingness to pay) will be excluded, unless they provide some direct assessment of basic ecological or social units (See Laurans et al [25] for such a review). Studies that describe methodologies, such as protocols or manuals, or conservation spatial planning tools, with no reference to case study applications will also be excluded.

No time limitation to the search will be applied to the search. However, two factors may result in some bias towards studies more recently published, i.e. literature in the format of Word/PDF documents or digitized library prints, and the context in which the term of ecosystem service has been cited, i.e. being relatively new and taken up in the last 25 years.

\section{Potential effect modifiers and reasons for heterogeneity}

For the purpose of the systematic map, reasons for heterogeneity, will not be considered (i.e. nonintervention variables that might influence the outcome [58]). However, we will collect data on region, country, geographical co-ordinates, spatial unit of analysis, crop type, farm type and biome. Future studies may consider other likely reasons for heterogeneity, including climate and agro-ecological zone, soil type, mineral texture class, topography (altitude and slope), species mix in cropping systems, previous land uses, other sources of income/livelihoods or development projects, amongst others.

\section{Study quality assessment}

In the case of a systematic map, the study will not seek to assess the quality of different types of evidence (e.g. use of controls, treatments, or baselines, account for environmental variability, and standardized sampling designs), but data are extracted that reflect the quality of studies. We will differentiate between studies that are experimental (studies estimating the impact of farming strategy using controls/treatments), quasi-experimental (without all factors affecting outcome or groups controlled) and non-experimental (no explicit manipulation of groups or design, including correlational, comparative, or longitudinal studies) (see Additional file 6). The study will include recommendations for reviewing the quality of studies or particular methodologies for a future systematic review(s), should they arise.

\section{Coding variables}

A standard coded questionnaire (Additional file 6) will be used to select and extract a subset of data from studies that have passed the full text screening stage, extracted by five reviewers. Data extracted will fall under three categories:

(1)Bibliographic information (publication type, author, journal title, year of publication, duration of study)

(2)Basic information of the study (region, country, geographical co-ordinates, spatial unit of analysis, crop type, farm type, biome)

(3) Primary ecosystem service (provisioning/supporting/ regulating/cultural) and subtype of ecosystem (e.g. nutrient cycling), site-specific conservation land management practice, methodology (experimental/ quasi-experimental/non-experimental), properties (physical/chemical/biological/social/economic) and indicators.

\section{Data mapping and presentation}

The output of the systematic map will be a technical report and a map. Summary statistics of study characteristics will be presented, together with a narrative synthesis in the discussion of general trends found in the literature. Methods of data presentation will depend on the accepted studies, but may include which indicators have been used to measure which land management strategies, or trends in the frequency, location, or duration of studies. In addition, a flow diagram will show the number of articles retrieved in the search, numbers passing each subsequent stage of screening, following PRISMA - Preferred Reporting Items for Systematic Reviews and Meta-Analyses [59]. An online interactive map will indicate temporal, thematic and spatial knowledge gaps. To enable such visualisation, background maps powered by OpenLayers (http://openlayers.org) and Google Maps (https://developers.google.com/maps/) are routinely used 
[60]. The database of sites can be created in PostgreSQL format (www.postgresql.org) and the mapping may be facilitated by PostGIS (http://postgis.refractions.net). The database of this nature normally contains geographical co-ordinates and background information about studies. This can enable the user to switch on and off the relevant fields of data, distinguished with coloured markers/shapes with a sliding timeline based on the year of publication.

Additional files will include:

(a) an Excel database of coded data for the systematic map,

(b) an EndNote database of all the studies included in the review, and

(c) an EndNote database of studies excluded at full text with reasons for exclusion.

\section{Discussion}

The study may illuminate the evolution of the study of conservation land management and ecosystem service provision in productive landscapes. The systematic map should contribute to a clearer understanding of what conservation land management strategies have been adopted on farms and what indicators have been used for their assessment. The results of the map will be used to critically reflect upon the state and scope of evidence and will help identify knowledge gaps to inform new research initiatives or future investments [41,61].

Should sufficient primary research exist, recommendations will be put forward for a full systematic review of a more narrowly defined question. Further development of the systematic map might include examination of the full text, or extension of the database coding and categorization.

A preliminary assessment has led us to some hypothesized trends of certain crops, regions, and ecosystem services that have been favoured. For example, systems commonly studied may include commodity crops of high global economic value and extent (e.g. coffee) or staple crops (e.g. rice or wheat). Regions commonly studied may be where there is high degradation and production potential, such as Brazil's cerrado, China's Loess Plateau, or Mexico's Chiapas. Positive effects of crop diversity may be more commonly studied in tropical than arid agro-ecosystems [62]. Certain ecosystem services may also have been favoured, such as those that are relatively simple to measure (e.g. soil), or those that provide direct goods for human consumption such as provisioning services (e.g. water) [63]. Other ecosystem services may have been discounted (e.g. cultural services), in part due to the subjective nature of perception and appreciation [15], and the need to apply anthropological methodologies that do not fall within the skillset of those typically conducting valuations, including ecologists and economists.

\section{Additional files}

Additional file 1: Expert workshops and list of participants.

Additional file 2: Search strings tested in Web of Science.

Additional file 3: Potential search strings tested in Web of Science.

Additional file 4: List of publications in test library.

Additional file 5: Rationale and classification process of countries included in the review.

Additional file 6: Categories (codebook) of data recorded for articles included in the database.

\section{Abbreviations}

ARIES: Artificial Intelligence for Ecosystem Services; CABI: CAB International (formally Commonwealth Agricultural Bureaux); CEE: Collaboration for Environmental Evidence; CCAFS: Climate Change Agriculture and Food Security; CICES: Common International Classification of Ecosystem Services; CIFOR: Centre for International Forestry Research; DFID: UK Department for International Foreign Development; DNA: Deoxyribonucleic acid; EBF: Evidence Based Forestry Initiative; ES: Ecosystem Service; EU: European Union; ESPA: Ecosystem Services and Poverty Alleviation; FAO: United Nations Food and Agricultural Organization; GHG: Green House Gas; GNI: Gross National Income; InVEST: Integrated Valuation of Ecosystem Services and Trade-offs; LIFDC: Low-Income Food Deficit Countries; MA: Millennium Ecosystem Assessment; MIMES: Multi-scale Integrated Models of Ecosystem Services; PRISMA: Preferred Reporting Items for Systematic Reviews and Meta-Analyses; REDD: Reduced Emissions from Deforestation and Degradation; OECD: Organization of Economic Co-operation and Development; PICO: Population Intervention Comparator Outcome; TEEB: The Economics of Ecosystems and Biodiversity; United Kingdom: UK; WB: World Bank; WOS: Web of Science.

\section{Competing interests}

The authors declare that they have no competing interests.

\section{Authors' contributions}

JT jointly with GP conceived the study and secured funding support. JT, JS, AW, KK, WZ, and GP co-wrote the manuscript. SB presented the mapping methodology. JT developed the data extraction strategy and built the test library, and will coordinate the mapping process, analysis and presentation of the results. JT will implement the search and screen the articles with four other reviewers. All authors read and approved the final manuscript.

\section{Acknowledgements}

This research is made possible through the financial and technical support of the Evidence-Based Forestry (EBF) Initiative of the Centre for International Forestry Research (CIFOR), supported through the United Kingdom's Department for International Development (DFID), Climate Change Agriculture and Food Security (CCAFS) and the University of Oxford Long-term Ecology Lab. The authors would like to thank the experts that attended the stakeholder workshop in Cape Town, South Africa and Oxford, UK at the launch of the review, and the advisory panel and anonymous reviewers for their feedback on earlier versions of the manuscript.

\section{Author details}

'Department of Zoology, Long-term Ecology and Resource Stewardship Laboratory, Biodiversity Institute, University of Oxford, Oxford, UK. ${ }^{2}$ Centre for Biological Sciences, University of Southampton, Southampton, UK. ${ }^{3}$ Edward Grey Institute, Department of Zoology, University of Oxford, Oxford, UK. ${ }^{4}$ Land Dynamics Department, Wageningen University, Wageningen, Netherlands. ${ }^{5}$ Centre for International Forestry Research, Bogor, Indonesia. ${ }^{6}$ Department of Geography, Faculty of Social Sciences, Open University, Milton Keynes, UK. ${ }^{7}$ Royal Botanical Gardens, Kew, UK. ${ }^{8}$ Department of Biology, University of Bergen, Bergen, Norway. 
Received: 17 October 2014 Accepted: 19 March 2015 Published online: 22 April 2015

\section{References}

1. Foresight. The future of food and farming executive summary. London, UK: The Government Office for Science; 2011.

2. UNESCO. UN World Water Development Report 4 - managing water under uncertainty and risk. Paris, France: UNESCO; 2012

3. FAO, WFP and IFAD. State of food insecurity in the world 2012: economic growth is necessary but not sufficient to accelerate reduction of hunger and malnutrition. Rome, Italy: FAO; 2012.

4. Tilman D, Balzer C, Hill J, Befort BL. Global food demand and the sustainable intensification of agriculture. Proc Natl Acad Sci. 2011;108(50):20260-4.

5. CCAFS. Food emissions. 2014 [10 August 2014]; Available from: http://ccafs.cgiar.org/bigfacts/\#.

6. Oxford Martin Commission. Now for the long term: report of the Oxford Martin Commission for Future Generations, Oxford Martin School. Oxford, UK: University of Oxford; 2013.

7. Dile YT, Karlberg L, Temesgen M, Rockström J. The role of water harvesting to achieve sustainable agricultural intensification and resilience against water related shocks in sub-Saharan Africa. Agr Ecosyst Environ. 2013:181:69-79.

8. Millennium Ecosystem Assessment. Ecosystems and human wellbeing: synthesis. Washington, DC: Island Press; 2005.

9. Steffan-Dewenter I, Kessler M, Barkmann J, Bos MM, Buchori D, Erasmi S, et al. Tradeoffs between income, biodiversity, and ecosystem functioning during tropical rainforest conversion and agroforestry intensification. Proc Natl Acad Sci. 2007;104(12):4973-8.

10. Cabell JF, Oelofse M. An indicator framework for assessing agro-ecosystem resilience. Ecol Soc. 2012;17(1):18

11. Goldman RL, Tallis H, Kareiva P, Daily GC. Field evidence that ecosystem service projects support biodiversity and diversify options. Proc Natl Acad Sci. 2008;105(27):9445-8.

12. Poppy GM, Chiotha S, Eigenbrod F, Harvey CA, Honzák M, Hudson MD, et al Food security in a perfect storm: using the ecosystem services framework to increase understanding. Phil Trans R Soc B. 2014;369:1-13.

13. Matzdorf $B$, Meyer $C$. The relevance of ecosystem services framework for developed countries' environmental policies a comparative case study of the US and EU. Land Use Policy. 2014;38:509-21.

14. Haines-Young R, Potchin M. Common International Classification for Ecosystem Service (CICES): Consultation on Version 4, August -December 2012 EEA Framework Contract No EEA/IEA/09/03; 2013.

15. TEEB, The Economics of Ecosystems and Biodiversity Ecological and Economic Foundations. Kumar P (ed). London, UK and Washington, USA: Earthscan; 2010

16. Maes J, Teller A, Erhard M, Liquete C, Braat L, Berry P, et al. Mapping and Assessment of Ecosystems and their Services. An analytical framework for ecosystem assessments under action 5 of the EU biodiversity strategy to 2020. Luxembourg: Publications office of the European Union; 2013.

17. UK NEA. United Kingdom National Ecosystem Assessment: understanding nature's value to society, Technical Report. Cambridge: UNEP-WCMC; 2011.

18. Schwartz MW, Brigham CA, Hoeksema JD, Lyons KG, Mills MH, Van Mantgem PJ. Linking biodiversity to ecosystem function: implications for conservation ecology. Oecologia. 2000;22:297-305.

19. De Bello F, Lavorel S, Diaz S, Harrington R, Cornelissen JHC, Bardgett RD, et al. Towards an assessment of multiple ecosystem processes and services via functional traits. Biodivers Conserv. 2010;19:2873-93.

20. Mace GM, Norris K, Fitter AH. Biodiversity and ecosystem services: a multilayered relationship. Trends Ecol Evol. 2012;27(1):19-26.

21. Wallace KJ. Classification of ecosystem services: problems and solutions. Biol Conserv. 2007:139(3-4):235-46.

22. Pullin AS, Knight T. Time to build capacity for evidence synthesis in environmental management. Environ Evid. 2013;2(21):1-2

23. Power AG. Ecosystem services and agriculture: tradeoffs and synergies. Philos Trans R Soc Lond B Biol Sci. 2010;365(1554):2959-71.

24. National Environment Research Council (NERC). Valuing Nature Programme. 2014 [12 June 2014]; Available from: http://www.valuing-nature.net/.

25. Laurans $Y$, Rankovic A, Bille R, Pirard R, Mermet $L$. Use of ecosystem services economic valuation for decision-making: questioning a literature blindspot. J Environ Manage. 2013;119:208-19.
26. Mupangwa W, Twomlow S, Walker S. Reduced tillage, mulching and rotational effects on maize (Zea mays L.), cowpea (Vigna unguiculata (Walp) L.) and sorghum (Sorghum bicolor L. (Moench)) yields under semi-arid conditions. Field Crop Res. 2012;132:139-48.

27. Leakey RB. Multifunctional Agriculture and Opportunities for Agroforestry: implications of IAASTD. In: Nair PKR, Garrity D, editors. Agroforestry-the future of global land use. Chapter 12. Netherlands: Springer; 2012. p. 203-14.

28. Friedrich T, Kienzle J, Kassam A. Conservation agriculture in developing countries: the role of mechanization. In: Innovation for sustainable agricultural mechanisation. Hanover, Germany: Food and Agricultural Organization; 2009.

29. Agamuthu P, Broughton WJ. Nutrient cycling within the developing oil palm-legume ecosystem. Agr Ecosyst Environ. 1985;13(2):111-23.

30. Ghimire R, Adhikari K, Chen Z, Shah SC, Dahal K. Soil organic carbon sequestration as affected by tillage, crop residue, and nitrogen application in rice-wheat rotation system. Paddy Water Environ. 2012;10(2):95-102.

31. Ricketts TH, Regetz J, Steffan-Dewenter I, Cunningham SA, Kremen C, Bogdanski $A$, et al. Landscape effects on crop pollination services: are there general patterns? Ecol Lett. 2008;11(5):499-515.

32. Aweto AO. Shifting cultivation and secondary succession in the tropics. Wallingford, UK: CABI International; 2013.

33. Trenbath BR. Intercropping for the management of pests and diseases. Field Crop Res. 1993;34(3-4):381-405.

34. Van der Hoek W, Sakthivadivel R, Renshaw M, Silver JB, Birley MH, Konradsen F. Alternate wet/dry irrigation in rice cultivation: a practical way to save water and control malaria and Japanese encephalitis? Colombo, Sri Lanka: International Water Management Institute; 2001.

35. Chapagain T, Riseman A, Yamaji E. Achieving more with less water: Alternate Wet and Dry Irrigation (AWDI) as an alternative to the conventional water management practices in rice farming. J Agric Sci. 2011;3(3):3-13.

36. Melero S, Panettieri M, Madejón E, Macpherson HG, Moreno F, Murillo JM. Implementation of chiselling and mouldboard ploughing in soil after 8 years of no-till management in SW, Spain: effect on soil quality. Soil Tillage Res. 2011;112(2):107-13.

37. Powlson DS, Stirling CM, Jat ML, Gerard BG, Palm CA, Sanchez PA, et al. Limited potential of no-till agriculture for climate change mitigation. Nature Clim Change. 2014;4(8):678-83.

38. Li C, Yue L, Kou Z, Zhang Z, Wang J, Cao C. Short-term effects of conservation management practices on soil labile organic carbon fractions under a rape-rice rotation in central China. Soil Tillage Res. 2012;119:31-7.

39. Carvalheiro LG, Veldtman R, Shenkute AG, Tesfay GB, Pirk CWW, Donaldson JS, et al. Natural and within-farmland biodiversity enhances crop productivity. Ecol Lett. 2011;14:251-9.

40. Mertz O, Ravnborg H, Lövei G, Nielsen I, Konijnendijk C. Ecosystem services and biodiversity in developing countries. Biodivers Conserv. 2007;16(10):2729-37.

41. Roe D, Fancourt M, Sandbrok C, Sibanda M, Giuliani A, Gordon-Maclean A. Which components or attributes of biodiversity influence which dimensions of poverty? Environ Evid. 2008;3(3):1-15.

42. Collaboration for Environmental Evidence. Guidelines for systematic reviews in environmental management. UK: Bangor University; 2013.

43. Ricketts TH, Daily GC, Ehrlich PR, Michener CD. Economic value of tropical forest to coffee production. Proc Natl Acad Sci U S A. 2004;101(34):12579-82.

44. Corbeels M, de Graaff J, Ndah TH, Penot E, Baudron F, Naudin K, et al. Understanding the impact and adoption of conservation agriculture in Africa: a multi-scale analysis. Agr Ecosyst Environ. 2014;187:155-70.

45. Corbeels M, Sakyi RK, Kühne RF and Whitbread A. Meta-analysis of crop responses to conservation agriculture in sub-Saharan Africa: Climate Change Agriculture and Food Security Report No. 12; 2014: Copenhagen, Denmark. p. 1-20.

46. Peh KSH, Balmford A, Bradbury RB, Brown C, Butchart SHM, Hughes FMR, et al. TESSA: a toolkit for rapid assessment of ecosystem services at sites of biodiversity conservation importance. Ecosystem Serv. 2013;5:51-7.

47. Glenn J, Gordon T, Florescu E. State of the future, millennium development project. Washington, DC: UN University; 2008.

48. van der Werf HMG, Petit J. Evaluation of the environmental impact of agriculture at the farm level: a comparison and analysis of 12 indicatorbased methods. Agr Ecosyst Environ. 2002;93(1-3):131-45.

49. Randolph J. Online Kappa Calculator. 2008 [3 July 2014]; Available from: http://justusrandolph.net/kappa/.

50. Fancourt M. DateX: systematic review extraction software. 2015: Cambridge, UK.

51. FAO. Final 2012 data and preliminary 2013 for major commodities aggregated. Rome, Italy: Statistics Division; 2013. 
52. Liquete C, Piroddi C, Drakou EG, Gurney L, Katsanevakis S, Chare A, et al. Current status and future prospects for the assessment of marine and coastal ecosystem services: a systematic review. PLoS One. 2013;8(7):1-15.

53. Ecosystem Services and Poverty Alleviation (ESPA). Regions of operation. 2014 [23 June 2014]; Available from: http://www.espa.ac.uk/our-work/regions.

54. FAO, Low-Income Food-Deficit Countries (LIFDC) - List for 2014. 2014. [2 April 2015]; Available from: http://www.fao.org/countryprofiles/lifdc/en/.

55. World Bank, Country and Lending Groups. 2014. [2 April 2015]; Available from: http://data.worldbank.org/about/country-and-lending-groups.

56. Zhang P, Wei T, Jia Z, Han Q, Ren X. Soil aggregate and crop yield changes with different rates of straw incorporation in semiarid areas of northwest China. Geoderma. 2014;230-231:41-9.

57. Sagie $H$, Morris $A$, Rofè $Y$, Orenstein DE, Groner E. Cross-cultural perceptions of ecosystem services: a social inquiry on both sides of the Israeli-Jordanian border of the Southern Arava Valley Desert. J Arid Environ. 2013:97:38-48.

58. Soderstrom B, Hedlund K, Jackson L, Katterer T, Lugato E, Thomsen I, et al. What are the effects of agricultural management on soil organic carbon (SOC) stocks? Environ Evid. 2014;3(2):1-8.

59. PRISMA. Preferred reporting items for systematic reviews and meta-analyses. 2009; Available from: http://www.prisma-statement.org/.

60. Peterson MP. Mapping the in cloud. New York, USA: The Guildford Press; 2014.

61. De Groot RS, Wilson MA, Boumans RMJ. A typology for the classification, description and valuation of ecosystem functions, goods and services. Ecol Econ. 2002:41:393-408.

62. Norfolk O, Eichhorn MP, Gilbert F. Traditional agricultural gardens conserve wild plants and functional richness in arid South Sinai. Basic Appl Ecol. 2013;14(8):659-69.

63. Boelee $E_{1}$ Chiramba T, Khaka E. An ecosystem services approach to water and food security in an ecosystem services approach to water and food security. Nairobi, Kenya, Colombo, Sri Lanka: International Water Management Institute and United Nations Environment Programme; 2011.

\section{Submit your next manuscript to BioMed Central and take full advantage of:}

- Convenient online submission

- Thorough peer review

- No space constraints or color figure charges

- Immediate publication on acceptance

- Inclusion in PubMed, CAS, Scopus and Google Scholar

- Research which is freely available for redistribution 